International Journal of Automotive and Mechanical Engineering (IJAME) ISSN: 2229-8649 (Print); ISSN: 2180-1606 (Online);

Volume 13, Issue 1 pp. 3248-3261, June 2016

OUniversiti Malaysia Pahang Publishing

DOI: http://dx.doi.org/10.15282/ijame.13.1.2016.11.0271

\title{
Jatropha oil methyl ester as diesel engine fuel - an experimental investigation
}

\author{
S. Jaichandar ${ }^{1 *}$ and K. Annamalai ${ }^{2}$ \\ ${ }^{1}$ Department of Automobile Engineering, \\ VelTech Technical University, Chennai, India \\ "Email: jaisriram18@yahoo.com \\ Phone: +919444984748 \\ ${ }^{2}$ Department of Automobile Engineering, Anna University, \\ Chennai, India
}

\begin{abstract}
The use of jatropha oil as a fuel for diesel engines is gaining more interest. Biodiesel is defined as a transesterified alternative fuel obtained from vegetable oils or animal fats having properties comparable to those of diesel. In the present investigation a methyl ester derived from jatropha oil (JOME) was considered as fuel. This paper presents a comparative study on the use of JOME and its blends of 20 and $50 \%$ on a volume basis with standard diesel as a source of fuel for a compression ignition engine. The engine tests were carried out at $0 \%, 25 \%, 50 \%, 75 \%$ and $100 \%$ load using a single-cylinder, fourstroke, constant speed diesel engine to study the performance, emission and combustion characteristics of these fuels. The results showed a $21 \%$ reduction in smoke, $17.9 \%$ reduction in $\mathrm{HC}$ emissions and $16 \%$ reduction in $\mathrm{CO}$ emissions for $20 \% \mathrm{JOME}$, with a $3.8 \%$ increase in $\mathrm{NO}_{\mathrm{x}}$ emission at full load. JOME and its blends showed a slight decrease in thermal efficiency and increase in the specific fuel consumption but at an acceptable level. There was a $2.8 \%$ decrease in brake thermal efficiency for the $20 \%$ JOME blend at full load. Among the blends, 20\% JOME showed better results compared to 50\% JOME and can be used as an alternative fuel in DI diesel engines.
\end{abstract}

Keywords: Biodiesel; Diesel engine; Emissions; Fuel consumption; Thermal efficiency.

\section{INTRODUCTION}

The energy needs of the world are increasing rapidly. The large increase in the number of automobiles in recent years has resulted in greater demand for petroleum products. The increase in energy demand, decrease in petroleum-based fuel reserves, increase in pollution caused by them and increasing fuel prices have focused attention on alternative sources of energy [1-5]. With crude oil reserves estimated to last only a few decades, there has been an active search for alternative fuels. Such alternative fuels in use today are bio-alcohols, hydrogen, natural gas and biodiesel [6-11]. Among the various alternative fuels under consideration, biodiesel derived from vegetable oils is the most promising alternative fuel to petroleum-based diesel fuel (PBDF) [12-15]. The advantages of biodiesel fuels are that they are renewable, can be produced locally, are cheap, have higher lubricity, a higher cetane number, minimal sulphur content and are less polluting for the environment compared to diesel fuel [16]. On the other hand, their disadvantages include the higher viscosity and pour point, and lower calorific value and volatility. Furthermore, their oxidation stability is lower, they are hygroscopic, and as solvents may cause corrosion in various engine components. 
Large numbers of studies on the performance, combustion and emission using raw vegetable oils and methyl or ethyl esters of sunflower oil [17], palm oil [7, 18-20], mahua oil [21], karanja oil [22, 23], soybean oil [24-27], rapeseed oil [28, 29] and rubber seed oil have been carried out on compression ignition (CI) engines. Studies have shown that the use of vegetable oils in the neat form is possible but not preferable. The high viscosity of vegetable oils and their low volatility affects the atomization and spray pattern of fuel, leading to incomplete combustion and severe carbon deposits, injector coking and piston ring sticking. Although transesterification reduces the viscosity of biodiesel [30] the viscosity was still found to be $60-85 \%$ higher than PBDF. Biodiesel has different but comparable fuel properties to those of diesel. Examples of these are the cetane number, heating value, density, and bulk modulus. Each respective fuel property changes the combustion and performance characteristics of biodiesel compared to diesel [16, 31, 32]. Hence, in order to obtain better performance from biodiesel it has to be blended with petroleum-derived diesel before it can be used in any diesel engine without modification [33]. As far as India is concerned, the use of non-edible oils for the production of biodiesel is found to be best suited given the insufficient supply of edible oils and the cost of their production. The planning commission of India has launched a biofuel project in 200 districts from 18 states in India. It has recommended two plant species, viz. jatropha (Jatropha curcas) and pongamia (Pongamia pinnata) for biodiesel production [11, 34-36]. Of these, Jatropha curcas, an excellent shrub having natural spread across the globe, is a promising biofuel crop ideally suited for growing in the wastelands of our country. Greater potential exists in India for bringing millions of hectares of wasteland under extensive plantation of jatropha, virtually converting unproductive lands into green oil fields. Jatropha has a long productive life of around 40 years and yields the biodiesel source, the seed, from the third year onwards.

In the present investigation, jatropha oil methyl ester was prepared from crude jatropha oil by transesterification using alkaline catalyst (single stage conversion) and its properties were determined. The performance and emission characteristics of JOME and its diesel blends were studied on a four-stroke single-cylinder direct-injection (DI) engine to check their feasibility as CI engine fuel.

\section{METHODS AND MATERIALS}

\section{Production of Jatropha Oil Methyl Ester}

To prepare jatropha oil methyl ester, the transesterification reaction was performed on raw jatropha oil. Transesterification is a chemical process of transforming large, branched, triglyceride molecules of vegetable oils and fats into smaller, straight chain molecules, very similar in size to the molecules of the species present in diesel fuel. The process takes place by chemically reacting the raw jatropha oil with methyl alcohol in the presence of catalyst. Biodiesel from jatropha was produced in a laboratory-scale setup, which consists of a heating mantle, reaction flask and mechanical stirrer. As a first step, the FFA content in the oil was estimated. Since the FFA of the raw oil was less than 5\%, a single-stage base transesterification process using methanol as reagent and $\mathrm{KOH}$ as catalyst was followed to produce biodiesel from jatropha oil [37, 38]. $1000 \mathrm{ml}$ of the vegetable oil was taken in the reaction vessel. About $18 \mathrm{gm}$ of $\mathrm{KOH}$ was mixed with 200 $\mathrm{ml}$ of methyl alcohol in a beaker. The mixture was added to the reaction vessel. Figure 1 shows the schematic diagram of the small-scale biodiesel production setup. 


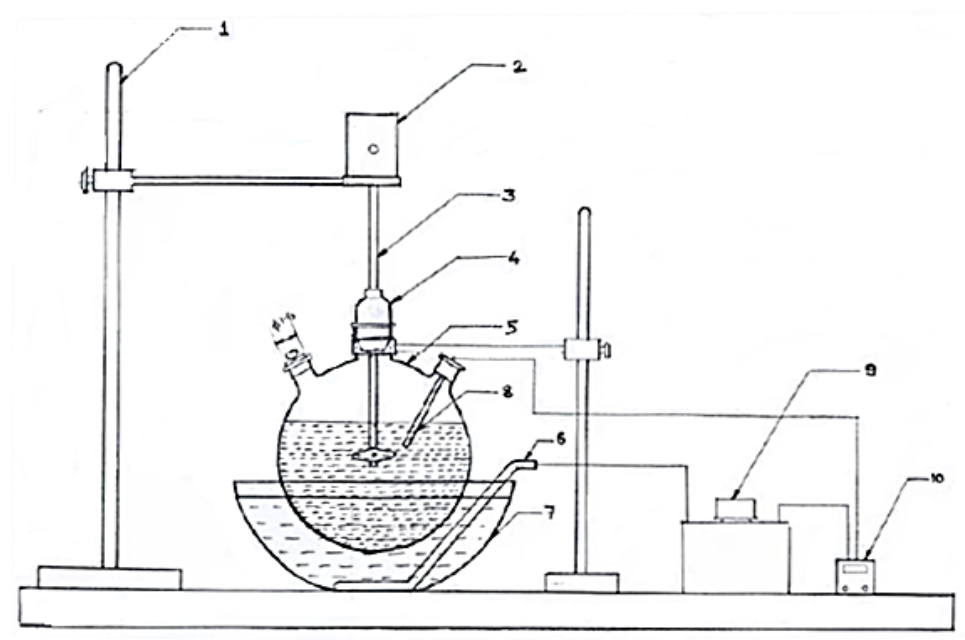

1. Stand

2. Stirrer Motor

3. Stirrer

4. Seal for stirrer

5. Three mouthed Reaction Vessel

6. Electric Heater

7. Oil Bath

8. Temperature probe

9. Temperature controller

10. Temperature indicator

Figure 1. Schematic diagram of small-scale biodiesel production setup

The reactor was immersed in a constant-temperature water bath maintained at $60^{\circ} \mathrm{C}$ and agitated vigorously with a mechanized stirrer. The temperature is maintained for about two hours with continuous stirring of the contents in the reaction vessel. The contents were allowed to settle in the vessel. After settling, the lower layer of glycerol was separated. The liquid remaining in the vessel was impure methyl ester which was washed with clean warm water to remove the impurities. Finally, the methyl esters were heated to $110^{\circ} \mathrm{C}$ to remove moisture present in them. Figure 2 shows the biodiesel production flow-chart. The properties of the raw jatropha oil and jatropha oil methyl ester were determined. The properties of the standard diesel oil, raw JOME and its $20 \%$ and $50 \%$ blends are given in Table 1. Most of the properties of JOME and its blends, like the calorific value, viscosity, density, flash point, cloud point and pour point, were comparable with those of diesel. However, the viscosity of the JOME was found to be about $44.1 \%$ higher and the calorific value was $2.9 \%$ lower, when compared to standard diesel.

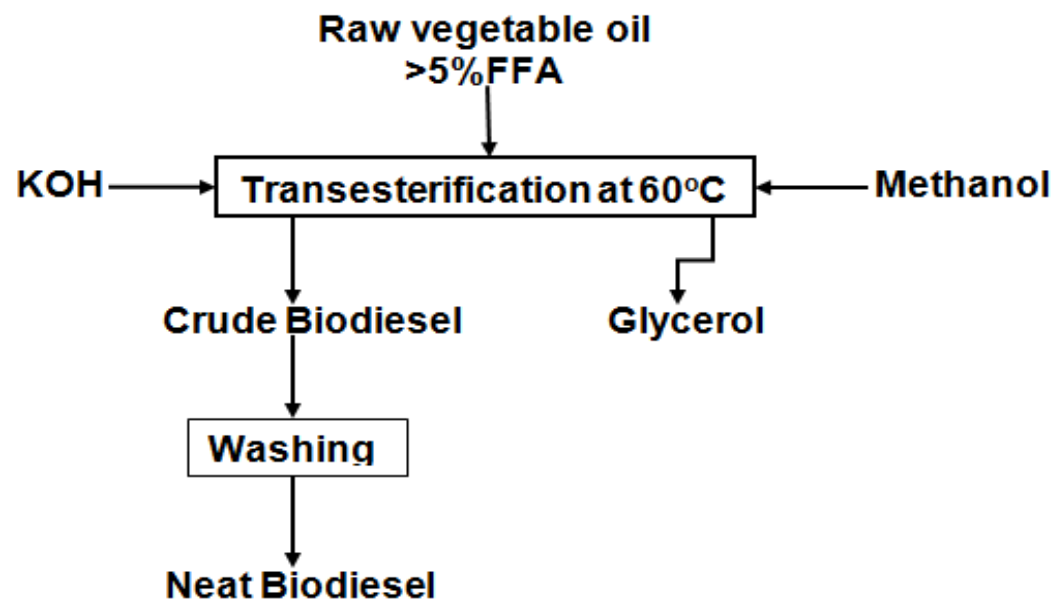

Figure 2. Biodiesel production flow-chart 
Table 1 Properties of diesel, biodiesel from jatropha and their blends.

\begin{tabular}{ccccccc}
\hline Oil & $\begin{array}{c}\text { Kinematic } \\
\text { viscosity } \\
(\mathrm{cSt})\end{array}$ & $\begin{array}{c}\text { Density } \\
\left(\mathrm{kg} / \mathrm{m}^{3}\right)\end{array}$ & $\begin{array}{c}\text { Calorific } \\
\text { value } \\
(\mathrm{MJ} / \mathrm{kg})\end{array}$ & $\begin{array}{c}\text { Flash Pt } \\
\left({ }^{\circ} \mathrm{C}\right)\end{array}$ & $\begin{array}{c}\text { Cloud Pt } \\
\left({ }^{\circ} \mathrm{C}\right)\end{array}$ & $\begin{array}{c}\text { Pour Pt } \\
\left({ }^{\circ} \mathrm{C}\right)\end{array}$ \\
\hline $\begin{array}{c}\text { Diesel } \\
100 \%\end{array}$ & 2.9 & 850 & 44 & 76 & 6.5 & 3.1 \\
$\begin{array}{c}\text { JOME } \\
50 \%\end{array}$ & 4.18 & 873 & 42.73 & 148 & 10.2 & 4.2 \\
$\begin{array}{c}\text { JOME } \\
20 \%\end{array}$ & 3.59 & 857 & 43.33 & 113 & 7.3 & 3.4 \\
JOME & 3.02 & 852 & 43.75 & 88 & 6.9 & 3.3 \\
\hline
\end{tabular}

\section{Test Equipment}

The test engine used was the Kirloskar, single-cylinder four-stroke air-cooled diesel engine, developing $4.4 \mathrm{~kW}$ at $1500 \mathrm{rpm}$. This engine was coupled to an eddy current dynamometer with control system. A chromel-alumel thermocouple in conjunction with a digital temperature indicator was used for measuring the exhaust gas temperature. The cylinder pressure was measured by a piezoelectric pressure transducer fitted on the engine cylinder head and a crank angle encoder fitted on the flywheel. Both the pressure transducer and encoder signal were connected to the charge amplifier to condition the signals for further processing. UBHC, $\mathrm{CO}$ and $\mathrm{NO}_{\mathrm{x}}$ emissions were measured using a 5gas analyser. The smoke intensity was measured with the help of a Bosch smoke meter. A 2-inch diameter filter paper was used to collect smoke samples from the engine, through the smoke sampling pump for measuring smoke intensity. Figure 3 shows the schematic diagram of the experimental setup.

1. Engine

2. Fuel Injection pump

3. Fuel Injection Nozzle

4. Intake Manifold

5. Intake Air Surge Tank

6. Air Cleaner

7. U-Tube Manometer

8. Fuel Tank

9. Crank Angle Detector

10. Electric Dynamometer

11. Exhaust Manifold

12. Compression Pressure Transducer

13. Injector Needle Lift Sensor

14. Dynamometer Control Panel

15. Exhaust Gas Analyzer

16. Smoke Meter

17. Digital Scope Recorder

18. Exhaust Gas Temp Sensor

19. EGR System

20. Exhaust Pipe

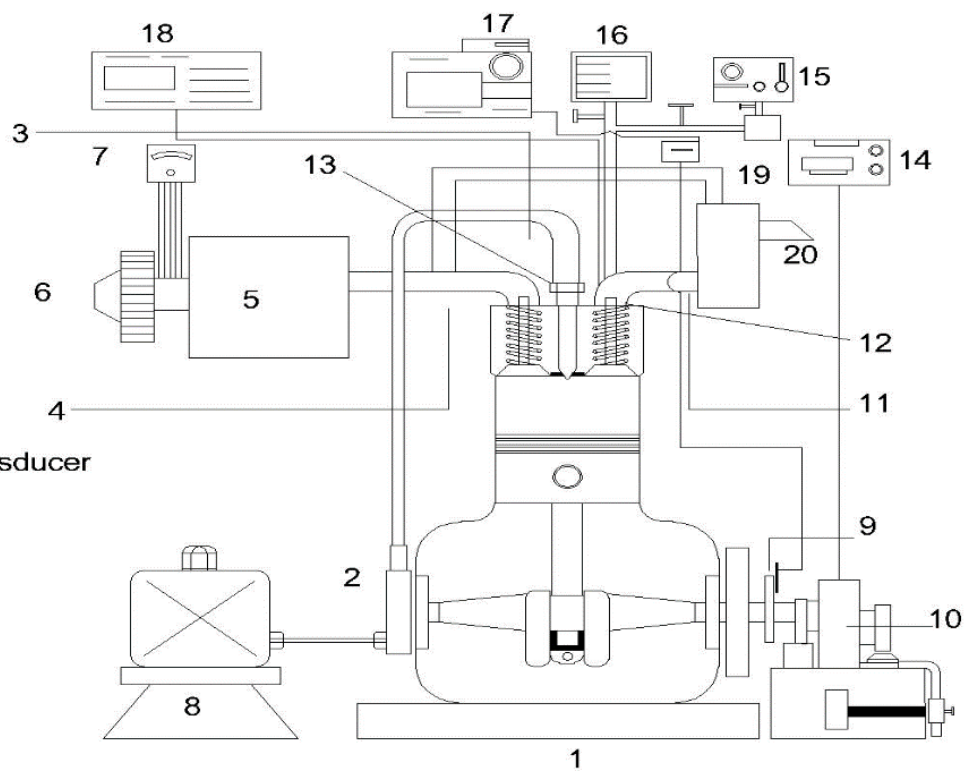

Figure 3. Schematic diagram of the experimental setup 


\section{Test Fuels and Method}

Four fuels were tested in this study: a neat 100\% JOME, diesel fuel, and blends of 50 and $20 \%$ JOME by volume in the diesel fuel. To start with, the performance, emissions and combustion tests were carried out using diesel fuel at various loads for the standard engine with manufacturer recommended fuel injection pressure and fuel injection timing of 200 bar and $23^{\circ}$ bTDC respectively. This performance and the combustion and emissions values were considered as baseline values throughout the experimentation for comparison with the results obtained from tests with 100\% JOME, 50\% JOME and 20\% JOME. The engine tests were carried out at $0 \%, 25 \%, 50 \%, 75 \%$ and $100 \%$ load and at a constant engine speed of $1500 \mathrm{rpm}$. In order to have a meaningful comparison of emissions and engine performance, tests were performed under the same operating conditions, i.e., the engine speed, torque, temperature and pressure conditions were maintained.

\section{RESULTS AND DISCUSSION}

Jatropha oil methyl ester and its blends were used separately as the fuel for a compression ignition engine without any engine modifications. The performance and emissions of the engine with diesel, blends of biodiesel and diesel and neat biodiesel are presented and discussed below.

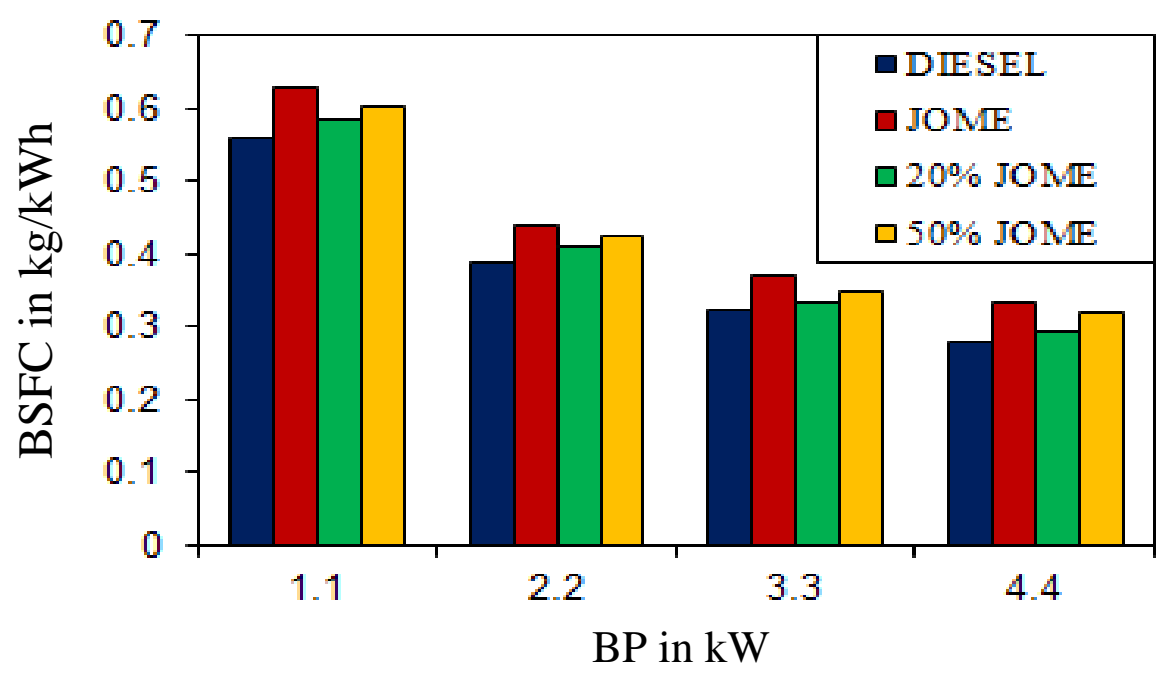

Figure 4. Variations of BSFC

\section{Brake Specific Fuel Consumption}

The brake specific fuel consumption (BSFC) is the ratio between the mass of fuel consumption and brake power. Figure 4 shows the BSFC of JOME, various blends of JOME with diesel, and diesel. At full load, JOME showed the highest fuel consumption. The BSFC for JOME and its blends was slightly higher than that of PBDF. The BSFC, in general, was found to increase with the increasing proportion of JOME in the PBDF. This can be attributed to the fact that the test engine had a mechanically controlled in-line type fuel injection pump; the engine load was controlled by the fuel injection volume. For the same volume, more JOME, based on the mass, was injected into the combustion chamber than that of PBDF due to its higher density. The BSFC for JOME, 50\% JOME and 20\% JOME, was higher than that of diesel by about $19.6 \%, 14 \%$, and $5.4 \%$ respectively at full 
load operation. Because the calorific value of the biodiesel fuel was lower than that of diesel, the BSFC of JOME and its blends was higher than that of diesel $[39,40]$.

\section{Brake Thermal Efficiency}

Thermal efficiency is the ratio between the power output and the energy introduced through fuel injection. Figure 5 shows the brake thermal efficiency of JOME and its blends. The brake thermal efficiency (BTE) of JOME and its blends was lower compared to that of diesel. At the rated load, the BTE of JOME was lower than that of PBDF by $8.5 \%$. The BTE of blends of JOME lie between those of diesel and JOME at all loads. The decrease in BTE at full load was $2.8 \%$ for $20 \%$ JOME and $5.25 \%$ for $50 \%$ JOME. The slight reduction of BTE with JOME and its blends can be attributed to the poor spray characteristics, poor air fuel mixing, higher viscosity, lower volatility and lower calorific value of biodiesel fuel than that of conventional diesel [41]. Apart from the factors stated earlier, another reason for the lower BTE could be that, since the engine was operated under constant injection advance and JOME had a smaller ignition delay [42], combustion was initiated well before TDC was reached. This increased the compression work and caused more heat loss and thus reduced the brake thermal efficiency of the engine.

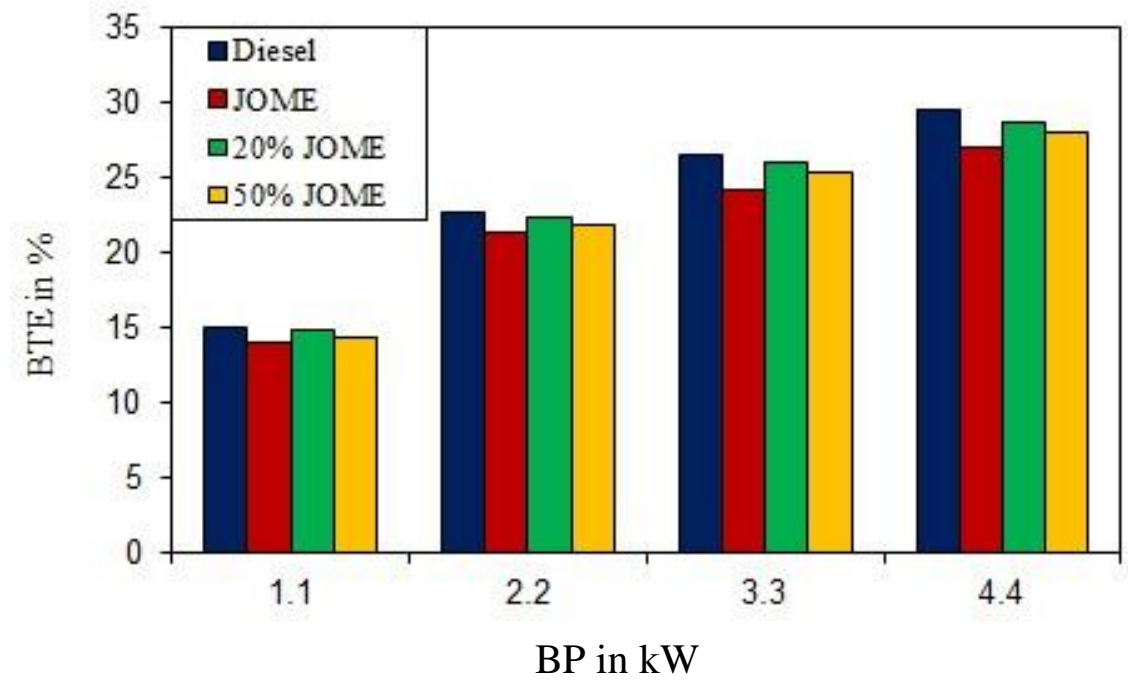

Figure 5. Comparison of BTE

\section{Unburnt Hydrocarbons Emission}

The unburnt hydrocarbon emissions with JOME and its blends are compared with diesel in Figure 6. UBHCs are the result of incomplete combustion of fuel and quenching of flame near the combustion chamber walls. These unburnt species are collectively known as UBHC emissions. UBHC emissions were reduced over the entire range of loads for JOME and its blends. They decreased with increase in the level of JOME in the blend. Since biodiesel is an oxygenated fuel $[43,44]$, it promotes combustion and results in a reduction in UBHC emissions. The UBHC emissions of JOME relative to diesel decreased by $57.5 \%$ at the rated load operation. 20\% JOME and 50\% JOME produced less $\mathrm{HC}$ emissions by $17.91 \%$ and $48.6 \%$ respectively at full load compared to those of standard diesel. 


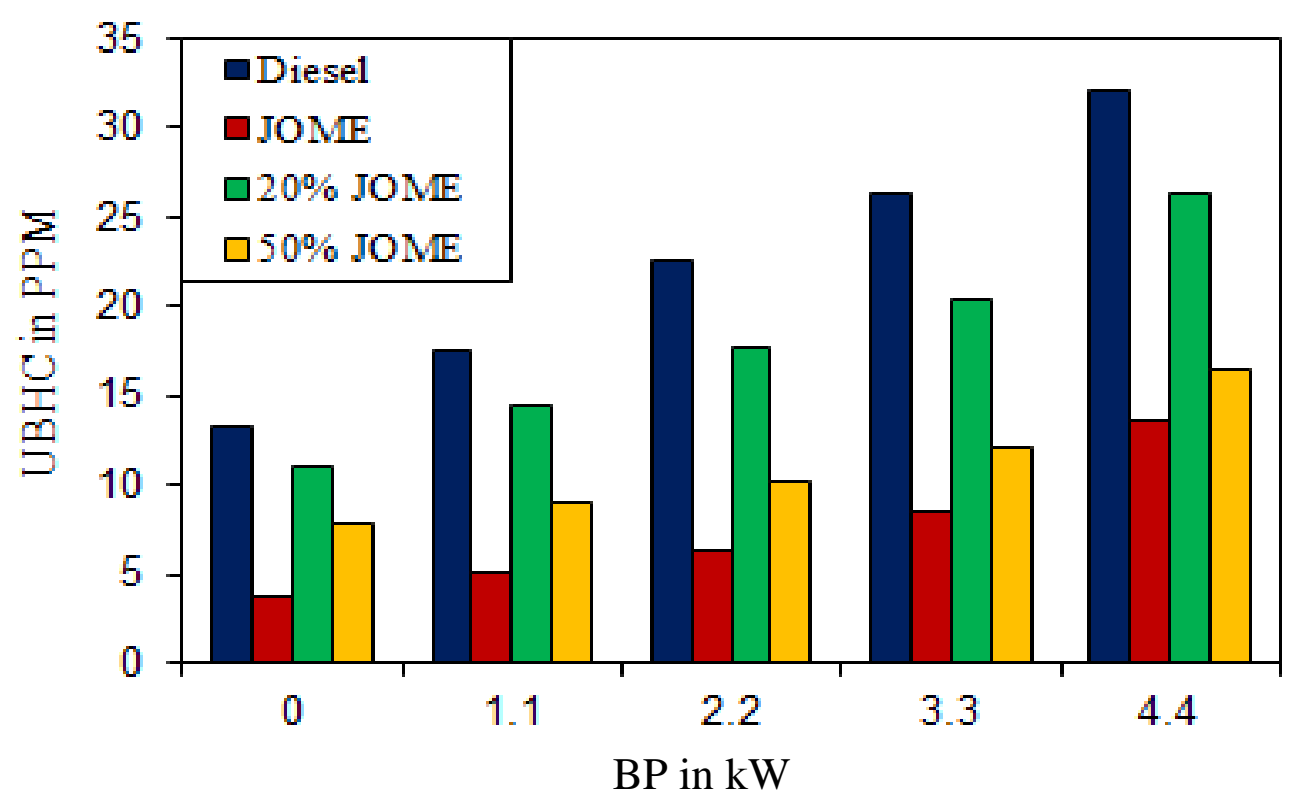

Figure 6. Variations of UBHC emission

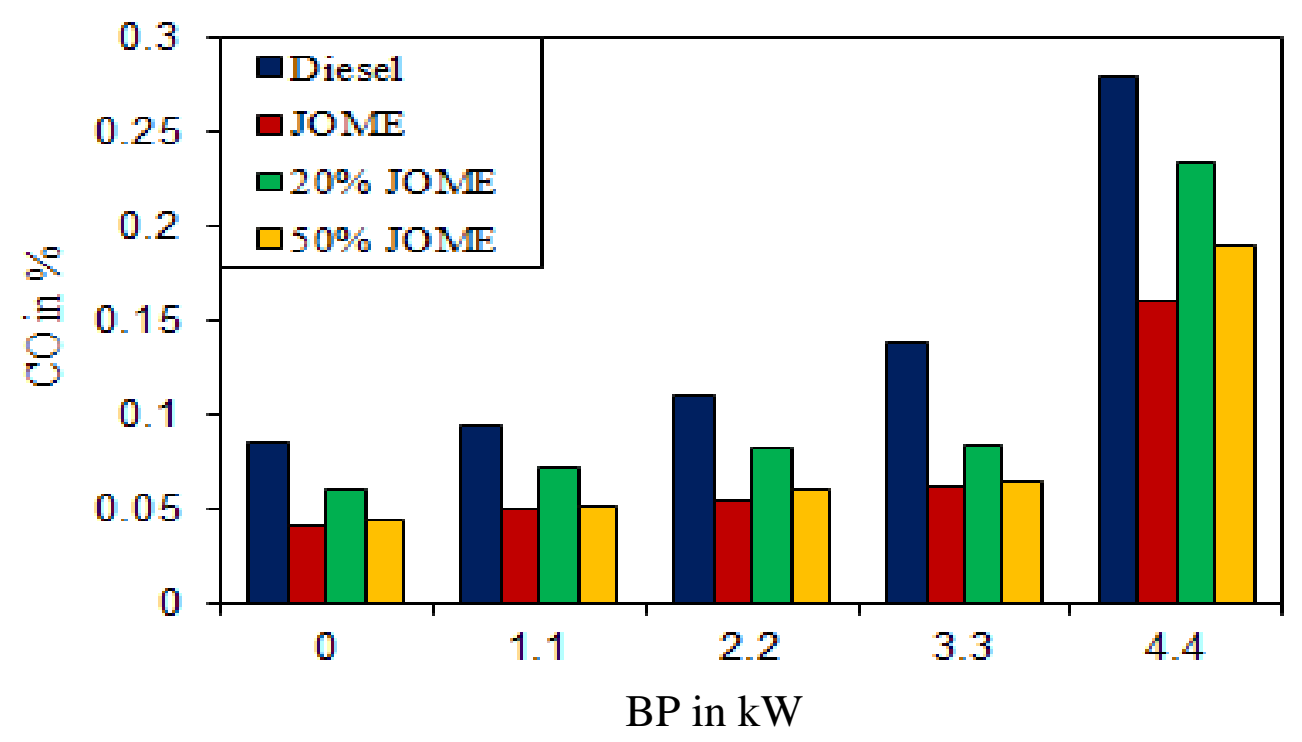

Figure 7. Variations of $\mathrm{CO}$ emission

\section{Carbon Monoxide Emission}

Carbon monoxide (CO) is an intermediate combustion product and is predominantly formed due to the lack of oxygen and incomplete combustion of fuel. Usually, high CO emissions are formed with fuel-rich mixtures, but as diesel combustion occurs with a lean mixture and has an abundant amount of air, the $\mathrm{CO}$ from diesel combustion is low. Figure 7 shows that carbon monoxide emissions were greatly reduced with the addition of JOME to diesel. They decreased with increase in the percentage of JOME in the blend. The lowest $\mathrm{CO}$ emissions were obtained for the JOME. It was noticed that $\mathrm{CO}$ varied from $0.085 \%$ by volume at low load to $0.28 \%$ by volume at full load for diesel and for JOME it varied from $0.042 \%$ by volume at low load to $0.16 \%$ by volume at full load. 
Similarly, at full load, CO emissions for $20 \%$ JOME ( $0.235 \%$ by volume) and $50 \%$ JOME $(0.19 \%$ by volume) were lower than those of diesel. $\mathrm{CO}$ is predominantly formed due to the lack of oxygen [45]. Since JOME is an oxygenated fuel, it led to better combustion of fuel, resulting in the decrease in $\mathrm{CO}$ emission. Reduction in $\mathrm{CO}$ emission is a strong advantage in favour of JOME.

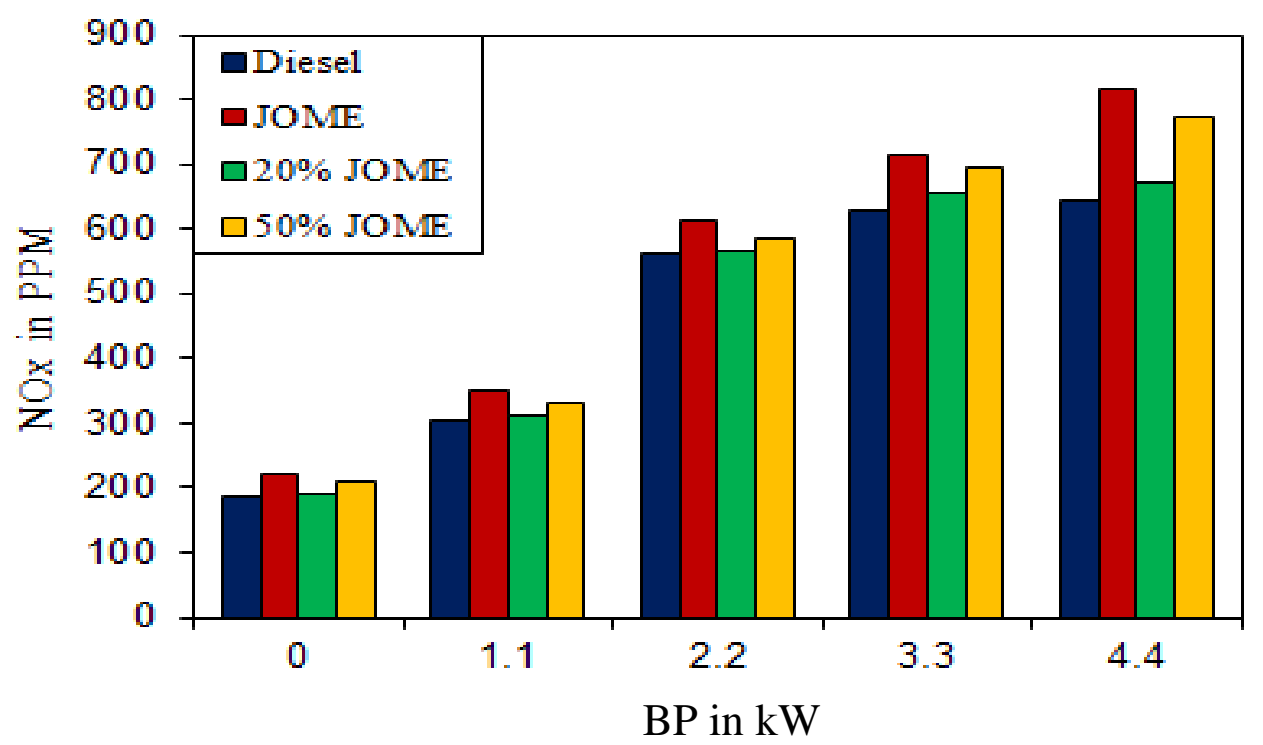

Figure 8. Comparisons of $\mathrm{NO}_{\mathrm{x}}$ emissions

\section{Nitrogen Oxides Emission}

Figure 8 shows an increase in the emission of oxides of nitrogen $\left(\mathrm{NO}_{\mathrm{x}}\right)$ with increase in the percentage of JOME in the fuel. Increases of $26.6 \%, 19.8 \%$ and $3.8 \%$ in $\mathrm{NO}_{\mathrm{x}}$ emissions for the JOME, 50\% JOME and 20\% JOME respectively were observed at full load compared to diesel. The $\mathrm{NO}_{\mathrm{x}}$ increase for JOME can be attributed to the oxygen content of the JOME, since the oxygen present in the fuel may provide additional oxygen for $\mathrm{NO}_{\mathrm{x}}$ formation [43, 44]. Another reason for the increase in $\mathrm{NO}_{\mathrm{x}}$ could be the possibility of higher combustion temperatures arising from improved combustion. It has to be noted that a larger part of the combustion was completed before TDC for JOME and its blends compared to diesel due to their lower ignition delay [42]. So it was highly possible that higher peak cycle temperatures were reached for JOME and its blends compared to diesel. However $\mathrm{NO}_{\mathrm{x}}$ can be controlled by adopting Exhaust Gas Recirculation and by employing suitable catalytic converters.

\section{Smoke}

Figure 9 shows the smoke intensity of diesel, JOME and its blends. The use of JOME, $50 \%$ JOME and 20\% JOME caused a reduction in smoke in the range of 56\%, 47\% and $21 \%$ respectively with respect to diesel at the rated load. A vast reduction in smoke intensity was observed with increase in the percentage of JOME in the blend, especially at high loads. JOME and its blends as fuel in diesel engines significantly reduce smoke. This was due to more complete combustion and the presence of oxygen in the JOME [3]. Other reasons for smoke reduction when using biodiesel can be attributed to the lower $\mathrm{C} / \mathrm{H}$ ratio and absence of aromatic compounds as compared with diesel. 


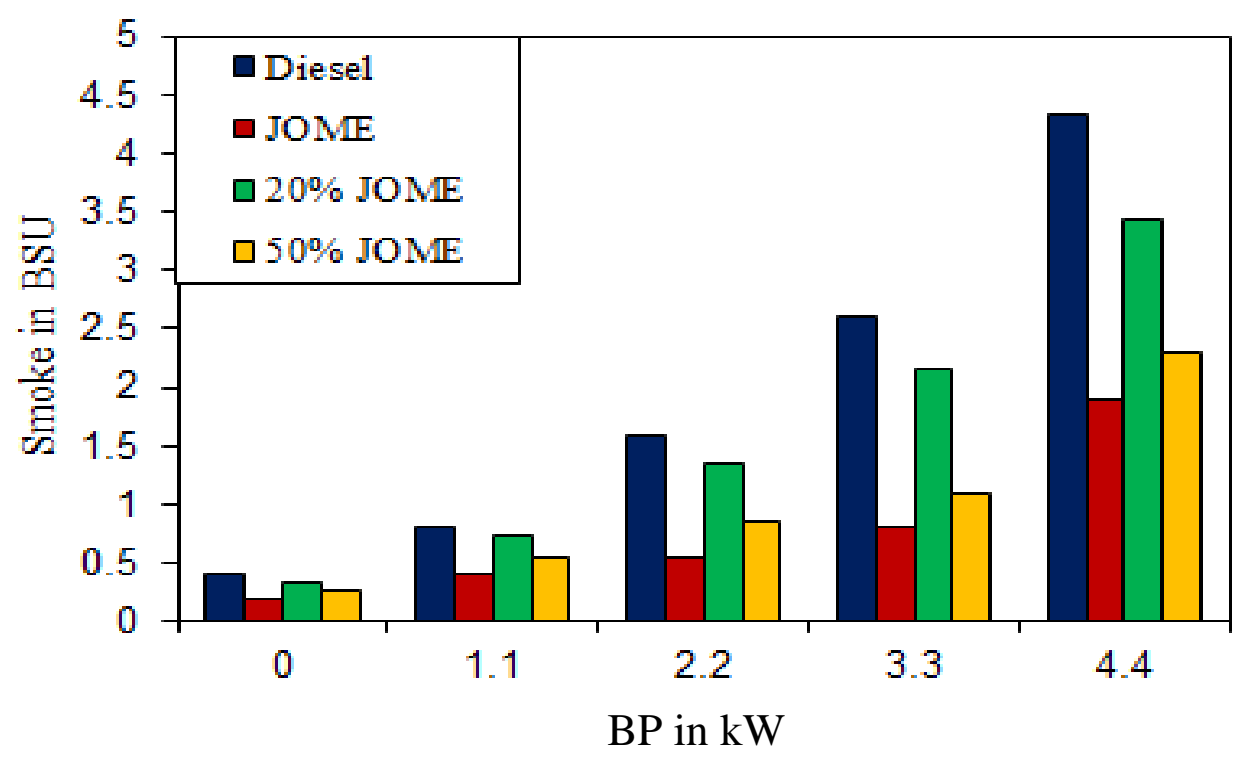

Figure 9. Comparison of smoke emissions

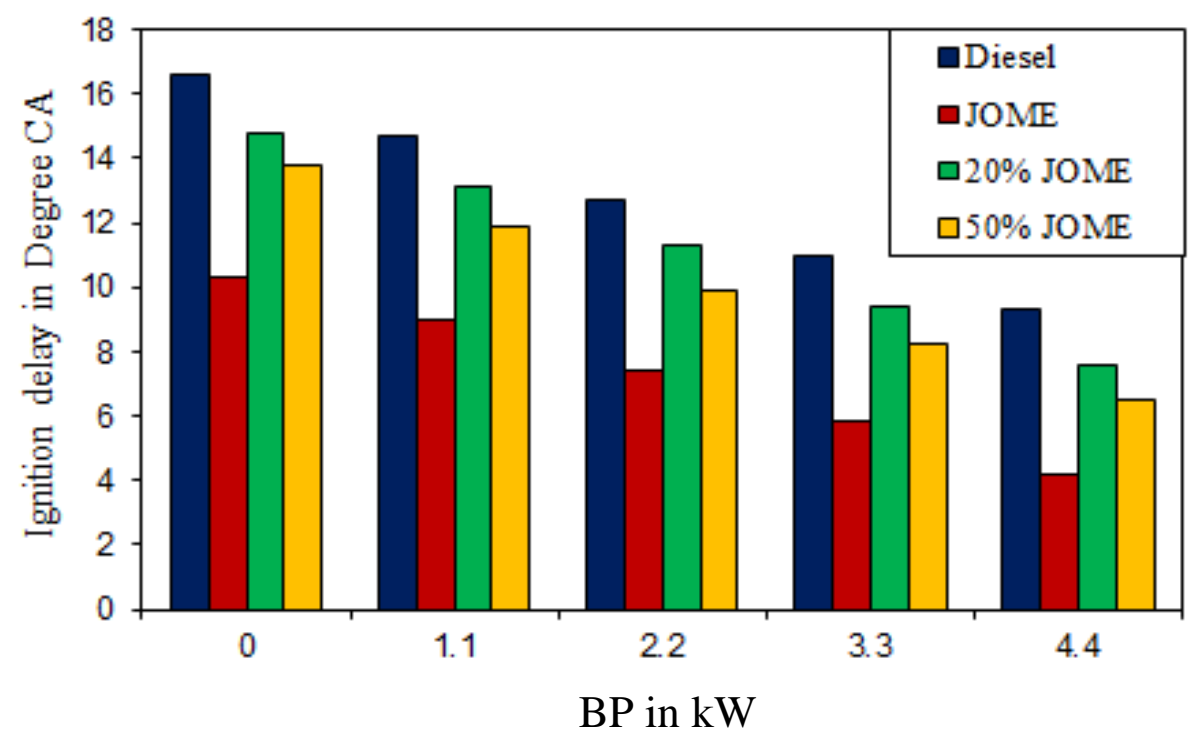

Figure 10. Variations of ignition delay

\section{Ignition Delay}

Ignition delay of fuel is a significant parameter in determining the knocking characteristics of CI engines. The cetane number of a fuel, which indicates the selfigniting capability, has a direct impact on ignition delay. The higher the cetane number, the shorter the ignition delay, and vice versa. Figure 10 shows the ignition delay of diesel, JOME and its blends. The ignition delays for JOME, 50\% JOME and 20\% JOME fuel were $5.14^{\circ} \mathrm{CA}, 2.85^{\circ} \mathrm{CA}$ and $1.75^{\circ} \mathrm{CA}$ shorter respectively than that of the dieseloperated engine at full load operation. It was observed that the ignition delay periods of JOME and its blends were significantly shorter than that of diesel and decreased with the increase in \% JOME in the blend. This was due to the fact that the oleic and linoleic fatty acid methyl esters present in the JOME split into smaller compounds when it enters the combustion chamber, resulting in higher spray angles and hence causing earlier ignition 
[3]. This indicates that JOME and its blends had a higher cetane number compared to diesel. It was noticed that for all test fuels the reduction in ignition delay increased with the increase in load. This was due to the higher combustion chamber wall temperature and reduced exhaust gas dilution at higher loads [45].

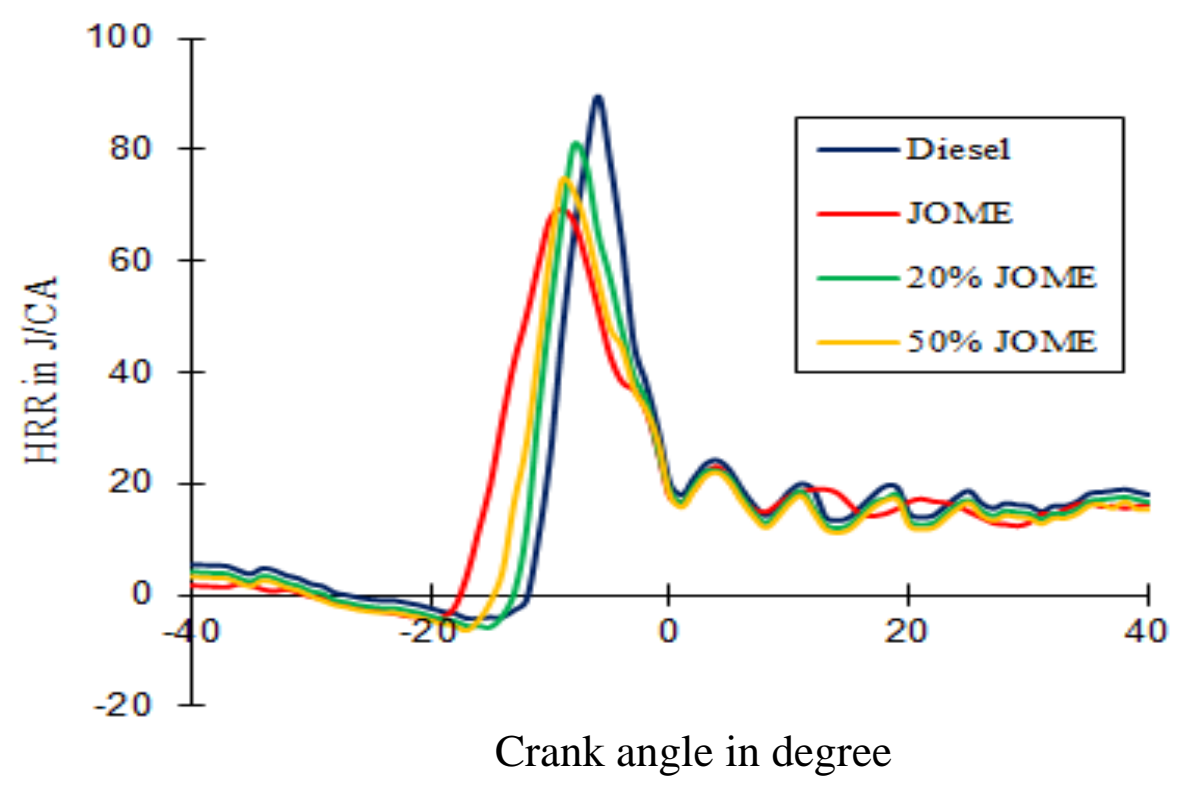

Figure 11. Comparisons of heat release rate

\section{Rate of Heat Release}

A thorough knowledge of the heat release pattern of a fuel is essential for the analysis of $\mathrm{NO}_{\mathrm{x}}$ formation inside the combustion chamber and the cooling system requirements of the engine [46]. The comparison of heat release rate variations for JOME and its blends with diesel is shown in Figure 11. It was observed that the maximum heat release rate of 89.69 J/deg CA was recorded for diesel at $6^{\circ} \mathrm{bTDC}$, while JOME recorded its maximum heat release rate of $69.481 \mathrm{~J} / \mathrm{deg} \mathrm{CA}$ at $8^{\circ} \mathrm{b}$ TDC. As the percentage of JOME in the blend increased, the maximum heat release rate decreased and the crank angle at which it took place advanced.

\section{CONCLUSIONS}

The fuel properties of JOME and its blends were comparable to those of diesel. Experiments were performed using a DI diesel engine to investigate the performance, emissions and combustion characteristics of biodiesel fuel derived from jatropha oil. The following conclusions were obtained.

i). Due to the lower calorific value of JOME, the specific fuel consumption increased and the brake thermal efficiency decreased with increase in the percentage of JOME in the fuel.

ii). Due to the higher oxygen content in the JOME, emissions of CO and UBHC decreased with increase in the percentage of JOME in the blend. It was also observed that there was a significant reduction in smoke intensity. The higher oxygen content in the JOME resulted in better combustion and increased the 
combustion chamber temperature. This increased the $\mathrm{NO}_{\mathrm{x}}$ emission of JOME compared to diesel.

iii). The ignition delay of JOME and its blends was found to be less than that of diesel. With increase in the percentage of JOME in the blend, the maximum heat release rate decreased.

iv). The results show a $2.8 \%$ decrease in brake thermal efficiency for the $20 \%$ JOME blend at full load. There was a $17.9 \%$ reduction in $\mathrm{HC}$ emissions and a $16 \%$ reduction in $\mathrm{CO}$ emissions, $21 \%$ reduction in smoke for the $20 \%$ JOME blend, with a $3.8 \%$ increase in $\mathrm{NO}_{\mathrm{x}}$ emission.

The present analysis reveals that biodiesel from jatropha oil is quite suitable as an alternative to diesel. From the combustion analysis it was found that the performance of the $20 \%$ JOME blend was as good as that of diesel. Taking these facts into account, a blend of 20\% JOME can be used as a suitable alternative fuel in DI diesel engines.

\section{REFERENCES}

[1] Hasan M, Rahman M, Kadirgama K. A review on homogeneous charge compression ignition engine performance using biodiesel-diesel blend as a fuel. International Journal of Automotive and Mechanical Engineering. 2015;11:2199.

[2] Ramadhas A, Jayaraj S, Muraleedharan C. Use of vegetable oils as IC engine fuels - a review. Renewable energy. 2004;29:727-42.

[3] Chauhan BS, Kumar N, Cho HM. A study on the performance and emission of a diesel engine fueled with Jatropha biodiesel oil and its blends. Energy. 2012;37:616-22.

[4] Kumar S, Chaube A, Jain SK. Experimental evaluation of CI engine performance using diesel blended with Jatropha biodiesel. International Journal of Energy and Environment. 2012;3:471-84.

[5] Ramasamy D, Yuan GC, Bakar RA, Zainal ZA. Validation of road load characteristic of a sub-compact vehicle by engine operation. International Journal of Automotive and Mechanical Engineering. 2014;9:1820-31.

[6] Yasin MHM, Mamat R, Aziz A, Yusop AF, Ali MH. Investigation on combustion parameters of palm biodiesel operating with a diesel engine. Journal of Mechanical Engineering and Sciences. 2015;9:1714-26.

[7] Said NH, Ani FN, Said MFM. Review of the production of biodiesel from waste cooking oil using solid catalysts. Journal of Mechanical Engineering and Sciences. 2015;8:1302-11.

[8] Mat Yasin MH, Mamat R, Sharma KV, Yusop AF. Influence of palm methyl ester (PME) as an alternative fuel in multicylinder diesel engine. Journal of Mechanical Engineering and Sciences. 2012;3:331-9.

[9] Shukri MR, Rahman MM, Ramasamy D, Kadirgama K. Artificial neural network optimization modeling on engine performance of diesel engine using biodiesel fuel. International Journal of Automotive and Mechanical Engineering. 2015;11:2332-47.

[10] Hasan MM, Rahman MM. Homogeneous charge compression ignition combustion: Advantages over compression ignition combustion, challenges and solutions. Renewable and Sustainable Energy Reviews. 2016; 57:282-91. 
[11] Nayak C, Pattanaik BP, Nayak SK. Effect of Preheated jatropha oil and jatropha oil methyl ester with producer gas on diesel engine performance. International Journal of Automotive and Mechanical Engineering. 2014;9:1709-22.

[12] K Kalyani R, S Naga S, EL N. Performance and emission characteristics of CI engine operated on vegetable oils as alternate fuels. International Journal of Automotive and Mechanical Engineering. 2011;4:414-27.

[13] Nematizade P, Ghobadian B, Najafi G. Investigation of fossil fuels and liquid biofuels blend properties using artificial neural network. International Journal of Automotive and Mechanical Engineering. 2012;5:639-47.

[14] Agarwal AK, Rajamanoharan K. Experimental investigations of performance and emissions of Karanja oil and its blends in a single cylinder agricultural diesel engine. Applied Energy. 2009;86:106-12.

[15] Kumar MS, Ramesh A, Nagalingam B. An experimental comparison of methods to use methanol and Jatropha oil in a compression ignition engine. biomass and bioenergy. 2003;25:309-18.

[16] Rostami S, Ghobadian B, Kiani Deh Kiani M. Effect of the injection timing on the performance of a diesel engine using diesel-biodiesel blends. International Journal of Automotive and Mechanical Engineering. 2014;10:1945-58.

[17] Kaufman KR, Ziejewski M. Sunflower methyl esters for direct injected diesel engines. Transactions of the ASAE. 1984;27:1626-33.

[18] Kalam M, Masjuki H. Biodiesel from palmoil — an analysis of its properties and potential. Biomass and Bioenergy. 2002;23:471-9.

[19] Sulaiman SA, Balamohan S, Moni MNZ, Atnaw SM, Mohamed AO. Feasibility study of gasification of oil palm fronds. Journal of Mechanical Engineering and Sciences. 2015;9:1744-57.

[20] Rihayat T, Salim S, Agusnar H, Fajri, Zaimahwati. Synthesis of polyurethane/clay nanocomposites based palm oil polyol coating. Journal of Mechanical Engineering and Sciences. 2015;9:1580-6.

[21] Puhan S, Vedaraman N, Sankaranarayanan G, Ram BVB. Performance and emission study of Mahua oil (Madhuca indica oil) ethyl ester in a 4-stroke natural aspirated direct injection diesel engine. Renewable Energy. 2005;30:1269-78.

[22] Raheman H, Phadatare A. Diesel engine emissions and performance from blends of karanja methyl ester and diesel. Biomass and Bioenergy. 2004;27:393-7.

[23] Teo AE, Yahya WJ, Romagnoli A, Rajoo S, Noor AM. Effectiveness of Series and Parallel Turbo Compounding on Turbocharged Diesel Engine. Journal of Mechanical Engineering and Sciences 8: 1448-1459.

[24] Canakci M. Performance and emissions characteristics of biodiesel from soybean oil. Proceedings of the Institution of Mechanical Engineers, Part D: Journal of Automobile Engineering. 2005;219:915-22.

[25] Haas MJ, Scott KM, Alleman TL, McCormick RL. Engine performance of biodiesel fuel prepared from soybean soapstock: a high quality renewable fuel produced from a waste feedstock. Energy and Fuels. 2001;15:1207-12.

[26] Scholl KW, Sorenson SC. Combustion of soybean oil methyl ester in a direct injection diesel engine. SAE Technical Paper; 1993.

[27] Azad AK, Rasul MG, Giannangelo B, Islam R. Comparative study of diesel engine performance and emission with soybean and waste oil biodiesel fuels. International Journal of Automotive and Mechanical Engineering. 2015;12:286681 . 
[28] Nwafor O, Rice G. Performance of rapeseed oil blends in a diesel engine. Applied Energy. 1996;54:345-54.

[29] Labeckas G, Slavinskas S. Performance of direct-injection off-road diesel engine on rapeseed oil. Renewable Energy. 2006;31:849-63.

[30] Barsic N, Humke A. Performance and emissions characteristics of a naturally aspirated diesel engine with vegetable oil fuels. SAE Technical Paper; 1981.

[31] Kowalewicz A, Wojtyniak M. Alternative fuels and their application to combustion engines. Proceedings of the institution of mechanical engineers, Part D: Journal of automobile engineering. 2005;219:103-25.

[32] Adam IK, A. Aziz AR, Yusup S. Determination of diesel engine performance fueled biodiesel (rubber seed/palm oil mixture) diesel blend. International Journal of Automotive and Mechanical Engineering. 2015;11:2675-85.

[33] Rahim R, Mamat R, Taib MY, Abdullah AA. Influence of fuel temperature on a diesel engine performance operating with biodiesel blended. International Journal of Advanced Science and Technology. 2012;43:115-26.

[34] Tewari D. Report of the committee on development of bio-fuel. Planning Commission, Government of India. 2003.

[35] Khalid A, Jaat N, Sapit A, Razali A, Manshoor B, Zaman I, et al. Performance and emissions characteristics of crude jatropha oil biodiesel blends in a diesel engine. International Journal of Automotive and Mechanical Engineering. 2015;11:2447-57.

[36] Vashist D, Ahmad M. Statistical analysis of diesel engine performance for castor and jatropha biodiesel-blended fuel. International Journal of Automotive and Mechanical Engineering. 2014;10:2155-69.

[37] Sahoo P, Naik S, Das L. Studies on biodiesel production technology from jatropha curcas and its performance in a CI engine. Journal of Agricultural Engineering. 2005;42:14-20.

[38] Murugesan A, Umarani C, Subramanian R, Nedunchezhian N. Bio-diesel as an alternative fuel for diesel engines - a review. Renewable and Sustainable Energy Reviews. 2009;13:653-62.

[39] Azad AK, Ameer Uddin SM, Alam MM. A Comprehensive study of di diesel engine performance withvegetable oil: an alternative bio-fuel source of energy. International Journal of Automotive and Mechanical Engineering. 2012;5:576-86.

[40] Azad AK, Rasul M, Giannangelo B, Islam R. Comparative study of diesel engine performance and emission with soybean and waste oil biodiesel fuels. International Journal of Automotive and Mechanical Engineering. 2015;12: 286681.

[41] Qi D, Lee C, Jia C, Wang P, Wu S. Experimental investigations of combustion and emission characteristics of rapeseed oil-diesel blends in a two cylinder agricultural diesel engine. Energy Conversion and Management. 2014;77:227-32.

[42] Sahoo P, Das L. Combustion analysis of Jatropha, Karanja and Polanga based biodiesel as fuel in a diesel engine. Fuel. 2009;88:994-9.

[43] Hoque N, Mourshed M, Das B. Performance and emission comparison of Karanja (pongamia pinnata), Pithraj (aphanamixis polystachya), Neem (azadira chtaindica) and Mahua (madhuca longofolia) seed oil as a potential feedstock for biodiesel production in Bangladesh. International Journal of Automotive and Mechanical Engineering. 2015;12: 2967-82. 
[44] Kaharudin K, Salehuddin F, Zain A, Aziz MA. Optimization of process parameter variations on leakage current in in silicon-on-insulator vertical double gate mosfet device.

[45] Ganesan V. Internal combustion engines: McGraw Hill Education (India) Pvt Ltd; 2012.

\section{NOMENCLATURE}

\begin{tabular}{|c|c|c|c|}
\hline JOME & jatropha oil methyl ester & PBDF & $\begin{array}{l}\text { petroleum-based diesel } \\
\text { fuel }\end{array}$ \\
\hline $20 \%$ JOME & $\begin{array}{l}\text { blend of } 20 \% \text { JOME with } \\
\text { diesel fuel by volume }\end{array}$ & $50 \%$ JOME & $\begin{array}{l}\text { blend of } 50 \% \text { JOME with } \\
\text { diesel fuel by volume }\end{array}$ \\
\hline CI & compression ignition & DI & direct injection \\
\hline BSFC & $\begin{array}{l}\text { brake specific fuel } \\
\text { consumption }\end{array}$ & FFA & free fatty acid \\
\hline BTE & brake thermal efficiency & UBHC & unburned hydrocarbons \\
\hline $\mathrm{CO}$ & carbon monoxide & bTDC & before top dead centre \\
\hline $\mathrm{NO}_{\mathrm{x}}$ & oxides of nitrogen & $\mathrm{CA}$ & crank angle \\
\hline
\end{tabular}

